Original Research Paper

\title{
The Bioaccumulation and Detoxification Mechanism of Neodymium on the Shoot of Rice Seedlings
}

\author{
Kailun Shi, Chengkun Liu, Keliang Lyu, Jie Chen and Xue Wang* \\ School of Life Sciences, Shandong University of Technology, Zibo, Shandong, 255049, China
}

\section{Article history}

Received: 22-01-2021

Revised: 05-03-2021

Accepted: 09-03-2021

Corresponding Author:

Xue Wang

School of Life Sciences,

Shandong University of

Technology, 255049, Zibo,

China

Email: xuewang@sdut.edu.cn

\begin{abstract}
Neodymium (Nd) potentially pollutes environment for its wide usage in agriculture and industry. In this study, the chemical forms of $\mathrm{Nd}$ and effect of $\mathrm{Nd}$ on rice shoots were studied after rice seedlings were exposed with $0,1,10,100$ and $1000 \mu \mathrm{M}$ Nd. The higher concentration of $\mathrm{Nd}$ inhibited shoot growth, but the lower concentration of $\mathrm{Nd}$ induced shoot growth. Six different chemical forms of Nd were present in shoot and the major forms of $\mathrm{Nd}$ were the insoluble phosphate and oxalate $\mathrm{Nd}$. The content of $\mathrm{Nd}$ was further detected in the soluble fractions, organelles and cell walls of rice shoot, respectively. $\mathrm{Nd}$ was mainly accumulated in the cell wall of shoot. The higher concentration of $\mathrm{Nd}$ decreased the content of $\mathrm{Ca}, \mathrm{K}, \mathrm{Mg}, \mathrm{Fe}, \mathrm{Mn}, \mathrm{Cu}$ and $\mathrm{Zn}$ in shoot. Moreover, the activities of antioxidant enzymes and the contents of Reactive Oxygen Species (ROS) were elevated by Nd treatments. Our results showed that the inactive oxalate or phosphate $\mathrm{Nd}$ was the major forms of $\mathrm{Nd}$ in rice shoot and the efficient sequestration into cell wall was a key detoxification pattern of $\mathrm{Nd}$ in the shoot of rice seedlings.With the wide usage of Rare Earth Elements (REEs) in agriculture, the detoxification mechanism of $\mathrm{Nd}$ in rice shoot was helpful for assessing the environmental safety of REEs.
\end{abstract}

Keywords: Neodymium, Uptake, Sequestration, Detoxification, Rice Seedlings

\section{Introduction}

Rare Earth Elements (REEs) have been widely used in the industries, high-technology factories, forestry and agriculture (Bergsten-Torralba et al., 2020; Gwenzi et al., 2018; Jiachen et al., 2006; Zhao and Yang, 2019). However, REEs will pollute environment, contaminate the plants and affect the food quality with the wide usage of REEs. The negative effect of REEs on the growth of crops has been observed as the soil surfaces are continuously polluted by REEs (Carpenter et al., 2015; Tang et al., 2017; Thomas et al., 2014).

Neodymium (Nd) is a light REEs existing in REEs Micro-Fertilizerand environment (Chen et al., 2019; Gwenzi et al., 2018). Nd has been extensively applied in the modern industries for its special chemical characteristics (Gwenzi et al., 2018; Kucuker et al., 2017; Nunes et al., 2017; Zakotnik et al., 2016). In the recent years, $\mathrm{Nd}$ has been treated as an emerging contaminant of environment (Carpenter et al., 2015; Kotelnikova et al., 2020; Liu et al., 2006; Zhao et al., 2019). However, as one of new pollutants in environment, there is still not enough information on the biological risks of $\mathrm{Nd}$.

Reactive Oxygen Species (ROS), including Hydrogen peroxide $\left(\mathrm{H}_{2} \mathrm{O}_{2}\right)$, Hydroxyl radical $(\mathrm{OH})$ and superoxide anion $\left(\mathrm{O}_{2}^{-}\right)$, are harmful for plants if the higher ROS levels are induced and exceed the detoxification capacity of plant cells. However, a number of enzymatic antioxidants and antioxidases can scavenge ROS in plant cells (Gill and Tuteja, 2010; Gill et al., 2015; Qi et al., 2018). It has been found that REEs could affect the level of ROS and activities of antioxidases (Liu et al., 2016; Sun et al., 2019; Zicari et al., 2018). Although $\mathrm{Nd}$ has become an emerging contaminant of environment, the detoxification mechanism of $\mathrm{Nd}$ in plants has not been systematically studied until now. Since rice is one of the most seriously polluted crops by REEs (Jiachen et al., 2006), the detoxification mechanism of $\mathrm{Nd}$ will be studied in the rice seedlings in this study. Furthermore, the bioaccumulation and effect of $\mathrm{Nd}$ on mineral nutrition elements and ROS levels were to be studied in the shoot of rice seedlings. 


\section{Materials and Methods}

\section{Plant Materials}

The seeds of rice (Oryza sativa L., cv. Zhonghua 11) were sterilized with $\mathrm{NaClO}(2 \%)$ and germinated in an artificial climate incubator $\left(26 \pm 2{ }^{\circ} \mathrm{C}\right)$. The seedlings were cultured in 1/10 Hoagland nutrient solution for 3 days. Then the nutrient solution was added $0,1,10,100$ and $1000 \mu \mathrm{M} \quad \mathrm{Nd}$ (by adding $\mathrm{Nd}\left(\mathrm{NO}_{3}\right)_{3}, \quad \mathrm{pH}$ 5.5), respectively. There were 3 replicates for each $\mathrm{Nd}$ treatments. Rice seedlings were collected after 10 days and the Fresh Weight (FW) and height of shoots (collected from 20 plants) were analyzed. Then the analysis on rice shoot samples was carried out as Fig. 1.

\section{Tissue Fractionation of $\mathrm{Nd}$ and the Different} Chemical Forms of Nd Analysis

The shoots samples were homogenized by using extraction buffer $(250 \mathrm{mM}$ sucrose, $1.0 \mathrm{~m}$ Mdithiothreitol $\left(\mathrm{C}_{4} \mathrm{H}_{10} \mathrm{O}_{2} \mathrm{~S}_{2}\right.$, $)$ and $50 \mathrm{mM} \mathrm{pH} 7.5$ Tris- $\left.\mathrm{HCl}\right)$. Three fractions, including cell wall, soluble fraction and organelle-containing fraction, were collected with the previous study (Weigel and Jager, 1980). In addition, the different forms of $\mathrm{Nd}$ were extracted with the deionized water, 2\% Acetic Acid (HAC), $1 \mathrm{M} \mathrm{NaCl}, 80 \%$ ethanol and $0.6 \mathrm{M} \mathrm{HCl}$, respectively (Zhang et al., 2014). Then three fractions and 6 chemical forms of $\mathrm{Nd}$ samples were subsequently oven dried at $65^{\circ} \mathrm{C}$ to dryness and digested with $\mathrm{HNO}_{3} / \mathrm{HClO}_{4}(\mathrm{v} / \mathrm{v}=3 / 1)$. Finally, $\mathrm{Nd}$ content was assayed with an Inductively Coupled Plasma Mass Spectrometer (ICP-MS, Agilent, Japan).

\section{Nd and Mineral Nutrition Elements Analysis}

A microwave-assisted digestion procedure was used to digest the shoot samples. Approximately $0.1 \mathrm{~g}$ shoot sample (Dry Weight, DW) and $10 \mathrm{~cm}^{3} \mathrm{HNO}_{3}$ was added into teflon bombs for digestion. Subsequently, the concentration of $\mathrm{Na}, \mathrm{Fe}, \mathrm{Mn}, \mathrm{Mg}, \mathrm{Zn}, \mathrm{K}, \mathrm{Ca}, \mathrm{Mo}$ and $\mathrm{Cu}$ were detected by an ICP-MS (Agilent, Japan).

\section{Cluster Analysis}

The software T Btools 0.665 (https://github.com/CJChen/TBtools) was used to perform cluster analysis and acquire the profiles of $\mathrm{Nd}$ abundance. TreeView of hierarchical clustering and the interactive heat-map were further analyzed.

\section{Assay Antioxidant Enzyme Activitiesand the Levels of $R O S$}

The activities of SOD, CAT and POD in rice seedlings were assayed with the previous methods (Goth, 1991; Liu et al., 2016; Oyanagui, 1984). Moreover, the contents of $\mathrm{H}_{2} \mathrm{O}_{2}, \mathrm{O}_{2}^{--}$, MDA and the soluble proteins were assayed according to the methods of previous studies, respectively (Bradford, 1976; Goth, 1991; Heath and Packer, 1968; Liu et al., 2016).

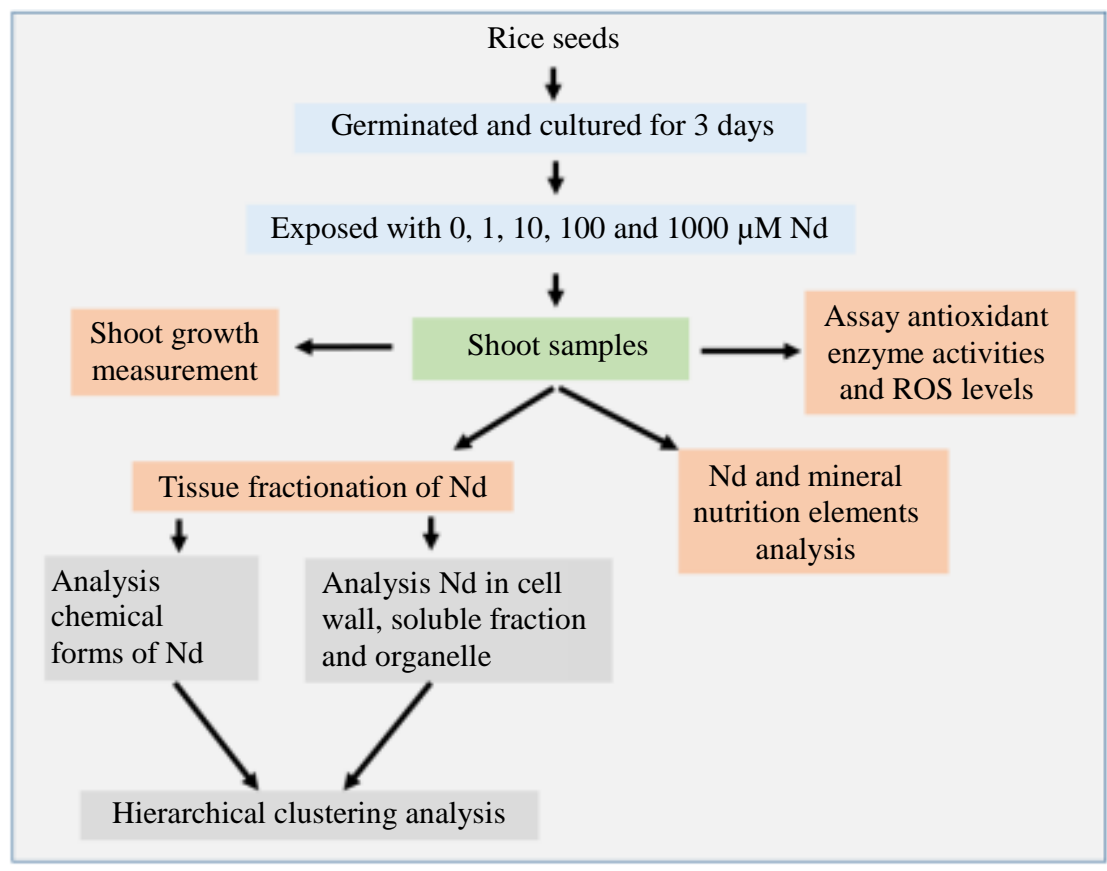

Fig. 1: The flowchart of the experimental procedures on the rice shoot. The seeds of rice were germinated and cultured for 3 days and the rice seedlings were exposed with $0,1,10,100$ and $1000 \mu \mathrm{M} \mathrm{Nd}$ for 10 days. Then the shoot samples were used for various of analysis 


\section{Statistical Analysis}

The data were presented as the mean \pm SEM and analyzed with the SPSS statistical software (16.0). The differences between $\mathrm{Nd}$ treatment groups were analyzed with one-way ANOVA (Tukey's test) at the significance level of $P<0.05$.

\section{Results}

\section{Effect of Nd on the Height and Weight of Shoots}

The treatments of 100 and $1000 \mu \mathrm{M}$ Nd significantly inhibited the height of shoots, but there was not any significant difference when rice was exposed with 1 and 10 $\mu \mathrm{M} \mathrm{Nd}$ (Table 1). Moreover, 1 and $10 \mu \mathrm{M} \mathrm{Nd}$ significantly increased, but 100 and $1000 \mu \mathrm{M} \mathrm{Nd}$ significantly decreased the fresh weight of shoots (Table 1).

\section{The Subcellular Distribution of Nd in Shoots}

The content of $\mathrm{Nd}$ was significantly enhanced in the soluble fractions, organelles and cell walls with the increase of Nd treatments (Fig. 2A). The accumulation of $\mathrm{Nd}$ in the soluble fractions and organelles was lower than that in the cell walls when rice was exposed with 10, 100 and 1000 $\mu \mathrm{M} \mathrm{Nd}$ (Fig. 2A). In addition, the content of $\mathrm{Nd}$ in the soluble fractions was lower than that in the cell organelles (Fig. 2A). The percentage of $\mathrm{Nd}$ in the cell walls was elevated (Fig. 2B), while the percentage of $\mathrm{Nd}$ in the cell organelles and soluble fractions was decreased with the increase of $\mathrm{Nd}$ treatments (Fig. 2B).

\section{The Different Chemical Forms of Nd in Shoots}

Six chemical forms of $\mathrm{Nd}$ included water-soluble $\mathrm{Nd}$, $\mathrm{Nd}$ binding with oxalate acid, inorganic $\mathrm{Nd}, \mathrm{Nd}$ integrated with pectate and protein, insoluble $\mathrm{NdPO}_{4}$ and $\mathrm{Nd}_{2}\left(\mathrm{HPO}_{4}\right)_{3}$, as well as $\mathrm{Nd}$ in residues. Six forms of $\mathrm{Nd}$

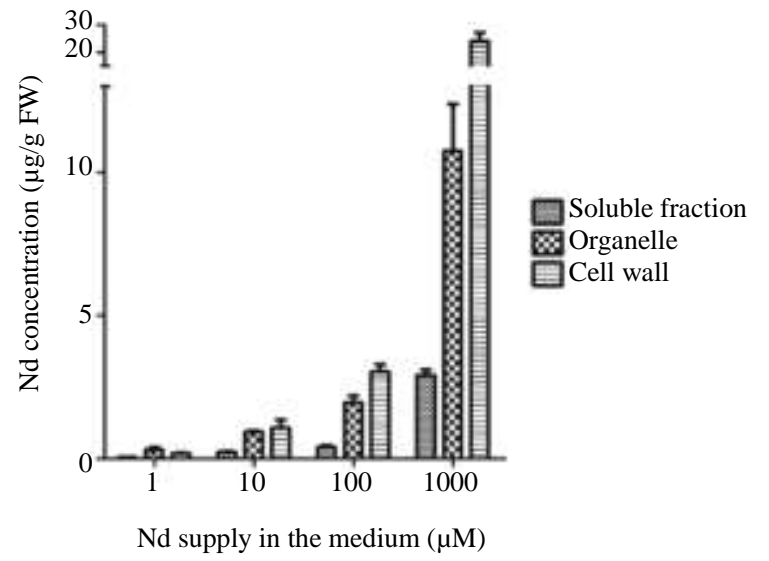

(a) were enhanced with the increase of $\mathrm{Nd}$ treatments in rice shoots (Fig. 3A). Moreover, the content of Nd extracted by $\mathrm{HCl}$ and $\mathrm{HAC}$ was higher than the other $4 \mathrm{Nd}$ forms (Fig. 3A). The percentage of Nd extracted by HAC was increased, but $\mathrm{Nd}$ extracted by $\mathrm{HCl}$ was decreased with the increase of $\mathrm{Nd}$ treatments in rice seedlings (Fig. 3B).

\section{Hierarchical Clustering Analysis}

The cluster map was made to show the chemical forms and intracellular location of $\mathrm{Nd}$ abundance in shoots by cluster analysis. The highest $\mathrm{Nd}$ accumulation was found in the cell walls (Fig. 4). However, the main forms of $\mathrm{Nd}$ were the $\mathrm{HCl}$-and HAc-extractable Nd (Fig. 4).

\section{Effect of Nd on the Content of Mineral Nutrition Elements in Shoots}

The content of $\mathrm{Ca}, \mathrm{K}$ and $\mathrm{Mg}$ was significantly decreased by $1000 \mu \mathrm{M} \mathrm{Nd}$ treatment in shoot (Table 2). However, the content of $\mathrm{Na}$ was not affected by the different concentration of Nd treatments (Table 2). The level of $\mathrm{Fe}, \mathrm{Mn}$ and $\mathrm{Cu}$ in shoot was significantly decreased by 100 and $1000 \mu \mathrm{M}$ Nd (Table 2) and Zn was decreased by 10,100 and $1000 \mu \mathrm{M} \mathrm{Nd}$ (Table 2).

\section{Effect of Nd on the Levels of ROS and SOD, POD and CAT Activities}

The treatments of 100 and $1000 \mu \mathrm{M} \mathrm{Nd}$ significantly increased the content of MDA and $\mathrm{H}_{2} \mathrm{O}_{2}$ in rice shoots (Table 3). At 10, 100 and $1000 \mu \mathrm{M} \mathrm{Nd}$, the level of $\mathrm{O}_{2}$. was significantly increased in the rice shoots (Table 3). The different Nd treatments significantly enhanced CAT and POD activities in shoots (Table 3). The activity of SOD was significantly induced by 10,100 and $1000 \mu \mathrm{M}$ $\mathrm{Nd}$ in the rice shoots (Table 3).

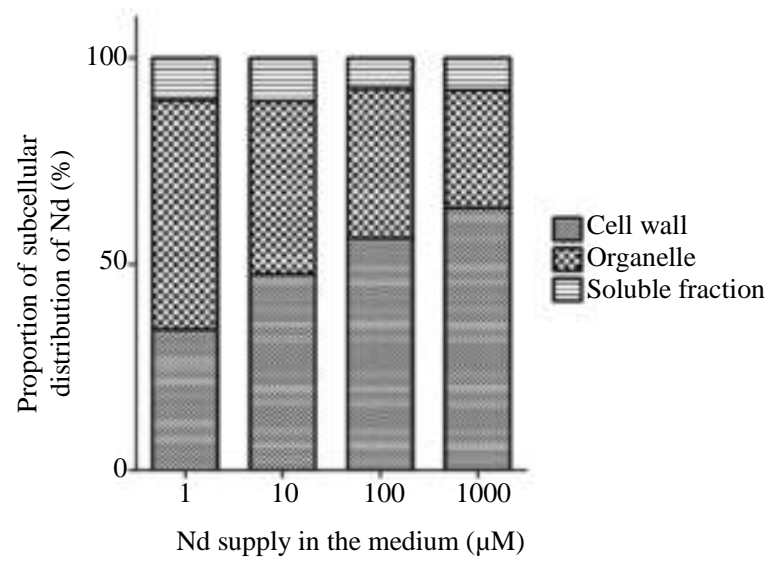

(b)

Fig. 2: The concentration and percentage of Nd in different subcellular fractions in the shoots of rice. (A) The concentration of Nd in different subcellular fractions in shoots. (B) The percentage of $\mathrm{Nd}$ in different subcellular fractions in shoots. Data are means \pm SEM $(\mathrm{n}=3)$. Means followed by the same letter do not differ significantly according to Tukey's test at $P<0.05$ 


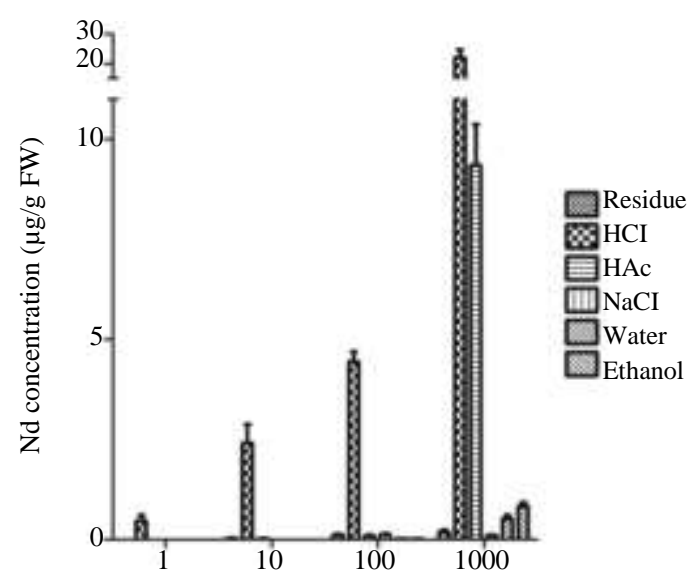

Nd supply in the medium $(\mu \mathrm{M})$

(a)

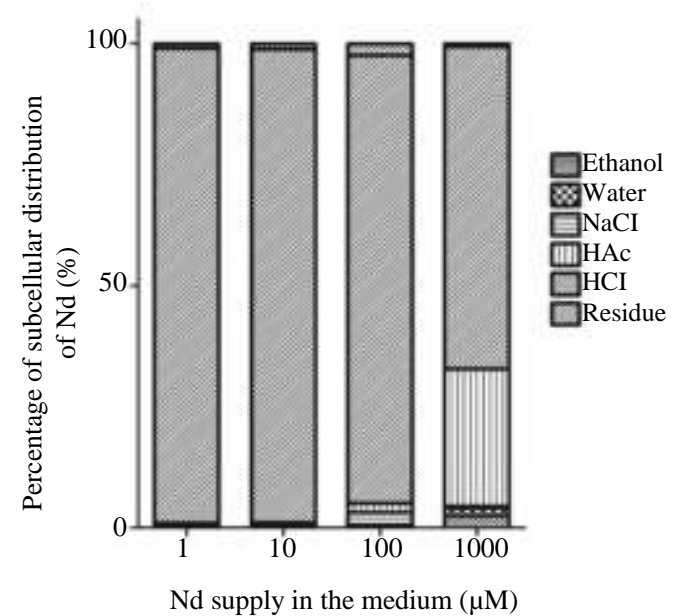

(b)

Fig. 3: The concentration and percentage of different chemical forms of $\mathrm{Nd}$ in the shoots of rice. (A) The concentration of different chemical forms of Nd in shoots; (B) The percentage of different chemical forms of Nd in shoots. Data are means \pm SEM $(n=$ 3). Means followed by the same letter do not differ significantly according to Tukey's test at $P<0.05$

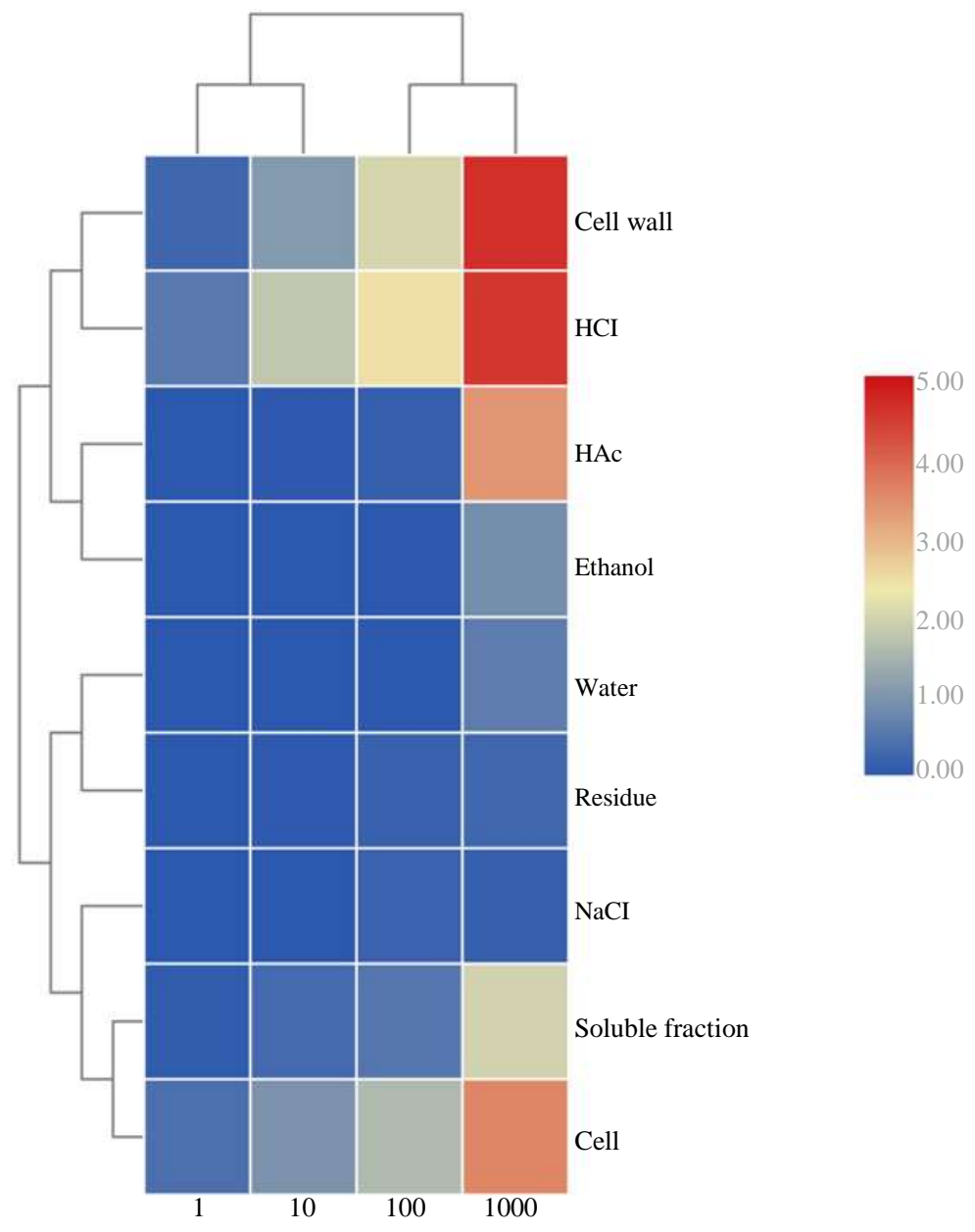

Fig. 4: Cluster map of intracellular location and chemical forms of $\mathrm{Nd}$ abundance level in shoots. The color weighting represents normalized levels of each variable from the high (red) to the low (blue) 
Table 1:The effect of Nd on shoot height and shoot fresh weight Nd concentration $(\mu \mathrm{M})$

\begin{tabular}{llllll} 
Morphological features & 0 & 1 & 10 & 100 & 1000 \\
\hline Shoot height $(\mathrm{cm})$ & $16.67 \pm 1.30^{\mathrm{a}}$ & $17.36 \pm 0.76^{\mathrm{a}}$ & $16.95 \pm 1.31^{\mathrm{a}}$ & $13.73 \pm 1.47^{\mathrm{b}}$ & $7.63 \pm 0.63^{\mathrm{c}}$ \\
Shoot fresh weight (g/plant) & $0.22 \pm 0.01^{\mathrm{a}}$ & $0.25 \pm 0.01^{\mathrm{b}}$ & $0.24 \pm 0.02^{\mathrm{c}}$ & $0.19 \pm 0.01^{\mathrm{d}}$ & $0.09 \pm 0.00^{\mathrm{e}}$ \\
\hline
\end{tabular}

Data are means \pm SEM $(\mathrm{n}=20)$. Means followed by the same letter do not differ significantly according to Tukey's test at $P<0.05$

Table 2: Effects of $\mathrm{Nd}$ on the content of nutrient elements in rice shoots $\mathrm{Nd}$ concentration in culture medium $(\mu \mathrm{M})$

\begin{tabular}{|c|c|c|c|c|c|}
\hline Element content & Control & 1 & 10 & 100 & 1000 \\
\hline$\overline{\mathrm{K}}(\mathrm{mg} / \mathrm{g} \mathrm{DW})$ & $33.43 \pm 0.96^{\mathrm{a}}$ & $34.11 \pm 2.35^{\mathrm{a}}$ & $32.22 \pm 2.17^{\mathrm{a}}$ & $30.61 \pm 1.44^{\mathrm{a}}$ & $24.93 \pm 1.18^{b}$ \\
\hline $\mathrm{Ca}(\mathrm{mg} / \mathrm{g} \mathrm{DW})$ & $1.09 \pm 0.03^{\mathrm{a}}$ & $1.04 \pm 0.11^{\mathrm{a}}$ & $0.95 \pm 0.21^{\mathrm{a}}$ & $0.76 \pm 0.13^{\mathrm{ab}}$ & $0.53 \pm 0.07^{\mathrm{b}}$ \\
\hline $\mathrm{Na}(\mathrm{mg} / \mathrm{g} \mathrm{DW})$ & $0.70 \pm 0.08^{\mathrm{a}}$ & $0.74 \pm 0.08^{\mathrm{a}}$ & $0.74 \pm 0.03^{\mathrm{a}}$ & $0.70 \pm 0.15^{\mathrm{a}}$ & $0.82 \pm 0.07^{\mathrm{a}}$ \\
\hline $\mathrm{Fe}(\mu \mathrm{g} / \mathrm{g} \mathrm{DW})$ & $318.95 \pm 8.43^{a}$ & $294.01 \pm 4.36^{\mathrm{a}}$ & $291.74 \pm 5.68^{a}$ & $242.94 \pm 30.25^{b}$ & $184.89 \pm 13.50^{c}$ \\
\hline $\mathrm{Mn}(\mu \mathrm{g} / \mathrm{g} \mathrm{DW})$ & $78.40 \pm 10.29^{a}$ & $78.41 \pm 3.11^{\mathrm{a}}$ & $68.16 \pm 5.07^{\mathrm{ab}}$ & $51.45 \pm 6.22^{b c}$ & $44.09 \pm 4.36^{c}$ \\
\hline $\mathrm{Cu}(\mu \mathrm{g} / \mathrm{g} \mathrm{DW})$ & $9.23 \pm 0.49^{a}$ & $8.40 \pm 0.83^{\mathrm{ab}}$ & $8.70 \pm 0.98^{a b}$ & $6.91 \pm 0.66^{\mathrm{b}}$ & $4.32 \pm 0.58^{c}$ \\
\hline
\end{tabular}

Data are means \pm SEM $(\mathrm{n}=3)$. Means followed by the same letter do not differ significantly according to Tukey's test at $P<0.05$

Table 3: Effect of Nd on enzymatic activities and the content of ROS in rice shoots

\begin{tabular}{|c|c|c|c|c|c|}
\hline \multirow[b]{2}{*}{ Parameters } & \multicolumn{5}{|c|}{ Nd concentration $(\mu \mathrm{M})$} \\
\hline & 0 & 1 & 10 & 100 & 1000 \\
\hline$\overline{\mathrm{CAT}}\left(\mu \mathrm{mol} \mathrm{H}_{2} \mathrm{O}_{2} / \mathrm{mg}\right.$ protein/min $)$ & $464.09 \pm 5.84^{\mathrm{a}}$ & $691.54 \pm 30.14^{\mathrm{b}}$ & $728.94 \pm 34.52^{\mathrm{b}}$ & $706.08 \pm 28.20^{\mathrm{b}}$ & $578.55 \pm 47.25^{a}$ \\
\hline SOD (units/mg protein) & $8.86 \pm 0.24^{\mathrm{a}}$ & $9.72 \pm 0.40^{\mathrm{a}}$ & $11.13 \pm 0.75^{\mathrm{b}}$ & $11.52 \pm 0.96^{\mathrm{b}}$ & $12.19 \pm 0.86^{\mathrm{b}}$ \\
\hline POD (units/min/mg protein) & $28.23 \pm 1.21^{\mathrm{a}}$ & $39.65 \pm 2.55^{\mathrm{b}}$ & $41.16 \pm 3.03^{\mathrm{b}}$ & $39.45 \pm 4.04^{\mathrm{b}}$ & $55.20 \pm 5.75^{\mathrm{c}}$ \\
\hline $\mathrm{MDA}(\mathrm{nmol} / \mathrm{g} \mathrm{FW})$ & $17.33 \pm 0.36^{\mathrm{a}}$ & $18.37 \pm 1.81^{\mathrm{a}}$ & $17.42 \pm 4.03^{\mathrm{a}}$ & $27.34 \pm 3.09^{b}$ & $33.42 \pm 3.52^{c}$ \\
\hline $\mathrm{H}_{2} \mathrm{O}_{2}(\mu \mathrm{mol} / \mathrm{g} \mathrm{FW})$ & $0.17 \pm 0.02^{\mathrm{a}}$ & $0.19 \pm 0.01^{\mathrm{a}}$ & $0.18 \pm 0.02^{\mathrm{a}}$ & $0.24 \pm 0.02^{\mathrm{b}}$ & $0.29 \pm 0.02^{\mathrm{c}}$ \\
\hline Generating rate of $\mathrm{O}_{2}^{-}\left(\mathrm{nmolO}_{2}{ }^{-} / \mathrm{min} / \mathrm{g} \mathrm{FW}\right)$ & $0.18 \pm 0.01^{\mathrm{a}}$ & $0.18 \pm 0.02^{\mathrm{a}}$ & $0.30 \pm 0.01^{\mathrm{b}}$ & $0.28 \pm 0.03^{\mathrm{b}}$ & $0.33 \pm 0.02^{c}$ \\
\hline
\end{tabular}

Data are means \pm SEM $(\mathrm{n}=3)$. Means followed by the same letter do not differ significantly according to Tukey's test at $P<0.05$

\section{Discussion}

It has been found that REEs could be accumulated in various of plants (Liu et al., 2020; Wang and Liu, 2017) and REEs was easily accumulated in the plants that grow in the REEs-enriched soil (Liu et al., 2020; Ma et al., 2017; Wang et al., 2001). In this study, the higher concentration of $\mathrm{Nd}$ inhibited the shoot growth, but the lower concentration of $\mathrm{Nd}$ had positive effects on the shoot growth of rice. In the previous studies, the growth of Lemna minor was enhanced by the lower concentration of cerium (Zicari et al., 2018) and the higher concentration of $\mathrm{La}$ inhibited plant growth (Agathokleous et al., 2018). Our results also showed that the lower concentration of Nd could induce shoot growth, which was consistent with these previous studies (Agathokleous et al., 2018; Salgado et al., 2020; Zicari et al., 2018).

It has been found that the toxic metals mainly exist in the cell wall, by which the toxicity of metal ions was decreased (Li et al., 2009; Weng et al., 2012). In the cell walls of plants, the negative charge sites were established by forming $\mathrm{Cd}$ coordination bonds with proteins, polysaccharides, carboxyl, hydroxyl, etc., (Krzesłowska,
2011; Küpper et al., 2000). The accumulation of cerium in cell walls plays a key role in the REEs' tolerance mechanism (Wang and Liu, 2017). In the present study, more $\mathrm{Nd}$ ions were deposited in the fraction of cell wall, which formed the first barrier for preventing Nd toxicity.

The toxicity of REEs was closely related to the chemical forms of REEs (Wang and Liu, 2017) and the different distribution patterns of REEs affected the growth of plants (Liu et al., 2020; Ma et al., 2017; Wang et al., 2001). The toxicity of $\mathrm{Cu}$ ions could be decreased by the formed bonds with phosphate (Rauser, 1999). In this study, there were more $\mathrm{Nd}$ ions bound with the low activity salt oxalate or phosphate in the rice shoots by cluster analysis. It showed that the bonds with salt oxalate or phosphate also play a role in the process of $\mathrm{Nd}$ detoxification. In addition, previous study showed that the toxicity of REEs was decreased by the combination with active amino acids and organic salts (Lai et al., 2006) and the toxicity of $\mathrm{Cu}$ could be decreased by binding with proteins and organic acids in vacuoles (Pilon et al., 2006). In this study, the partial Nd exists in the soluble fraction and vacuoles, which could further decrease the toxicity of $\mathrm{Nd}$ by binding with proteins and organic acids.

The over-production of ROS are also the toxic effects of REEs on plants (Peng and Zhou, 2009; Wang et al., 
2009). In this study, the higher concentration of $\mathrm{Nd}$ enhanced the production of ROS in shoots, which showed that the oxidative stress was induced by $\mathrm{Nd}$ accumulation in rice shoots. Nevertheless, for the activities of CAT, SOD and POD were induced in rice shoots, the oxidative stress could be efficaciously controlled by the increase of anti-oxidative enzyme activities in shoots.

The uptake of mineral elements is important for the growth of plants. In this study, the higher concentration of $\mathrm{Nd}$ decreased the content of $\mathrm{Ca}, \mathrm{K}, \mathrm{Mg}, \mathrm{Fe}, \mathrm{Mn}, \mathrm{Cu}$ and $\mathrm{Zn}$ in shoot. It showed that $\mathrm{Nd}$ affected the uptake of mineral elements in the rice shoots. For the mineral elements play a crucial role for plant growth, the decrease of mineral element content may lead to the growth inhibition of rice seedlings.

\section{Conclusion}

In summary, it is found that the higher concentration of $\mathrm{Nd}$ inhibited shoot growth, but the lower concentration $\mathrm{Nd}$ had positive effects on rice seedlings. $\mathrm{Nd}$ was mainly accumulated in the cell wall of rice shoot and $\mathrm{Nd}$ affected the level of ROS, the activities of antioxidant enzymes and the uptake of mineral elements in shoot. In addition, the inactive oxalate and phosphate $\mathrm{Nd}$ was the major forms of $\mathrm{Nd}$ in rice shoot. The efficient sequestration into cell wall was a crucial detoxification pattern of $\mathrm{Nd}$ in rice seedlings. With the wide usage of REEs in agriculture and industry, the detoxification mechanism of $\mathrm{Nd}$ in rice shoot was helpful for assessing the environmental safety of REEs.

\section{Acknowledgement}

This work was supported by Major Basic Research program of Shandong Natural Science Foundation (ZR2020ZD19), Natural Science Foundation of Shandong (ZR2014DM010) and National Natural Science Foundation of China (30900071).

\section{Author's Contributions}

Kailun Shi: Participated in all experiments and coordinated the data-analysis of the manscript.

Chengkun Liu and Keliang Lyu: Participated in all experiments and coordinated to the writing of the manscript.

Jie Chen: Participated in writing of the manuscript.

Chengkun Liu: Critical revision of the article.

Xue Wang: designed the research plan and organized the study.

\section{Ethics}

This article is original and contains unpublished material. The corresponding author confirms that all of the other authors have read and approved the manuscript and no ethical issues involved.

\section{References}

Agathokleous, E., Kitao, M., \& Calabrese, E. J. (2018). The rare earth element (REE) lanthanum (La) induces hormesis in plants. Environmental Pollution, 238, 1044-1047.

https://doi.org/10.1016/j.envpol.2018.02.068

Bergsten-Torralba, L. R., Magalhães, D. P., Giese, E. C., Nascimento, C. R. S., Pinho, J. V. A., \& Buss, D. F. (2020). Toxicity of three rare earth elements and their combinations to algae, microcrustaceans and fungi. Ecotoxicology and Environmental Safety, 201, 110795. https://doi.org/10.1016/j.ecoenv.2020.110795

Bradford, M. M. (1976). A rapid and sensitive method for the quantitation of microgram quantities of protein utilizing the principle of protein-dye binding. Analytical Biochemistry, 72(1-2), 248-254. 72, 248-254. https://doi.org/10.1006/abio.1976.9999

Carpenter, D., Boutin, C., Allison, J. E., Parsons, J. L., \& Ellis, D. M. (2015). Uptake and effects of six rare earth elements (REEs) on selected native and crop species growing in contaminated soils. PLoS One, 10(6), e0129936.

https://doi.org/10.1371/journal.pone.0129936

Chen, H., Chen, Z., Chen, Z., Ma, Q., \& Zhang, Q. (2019). Rare earth elements in paddy fields from eroded granite hilly land in a southern China watershed. PloS One, 14(9), e0222330.https://doi.org/10.1371/journal.pone.02 22330

Gill, S. S., \& Tuteja, N. (2010). Reactive oxygen species and antioxidant machinery in abiotic stress tolerance in crop plants. Plant Physiology and Biochemistry, 48(12), 909-930. https://doi.org/10.1016/j.plaphy.2010.08.016

Gill, S. S., Anjum, N. A., Gill, R., Yadav, S., Hasanuzzaman, M., Fujita, M., ... \&Tuteja, N. (2015). Superoxide dismutase-mentor of abiotic stress tolerance in crop plants. Environmental Science and Pollution Research, 22(14), 10375-10394. https://doi.org/10.1007/s11356-015-4532-5

Goth, L. (1991). A simple method for determination of serum catalase activity and revision of reference range. ClinicaChimicaActa, 196(2-3), 143-151. https://doi.org/10.1016/0009-8981(91)90067-m

Gwenzi, W., Mangori, L., Danha, C., Chaukura, N., Dunjana, N., \& Sanganyado, E. (2018). Sources, behaviour and environmental and human health risks of high-technology rare earth elements as emerging contaminants. Science of the Total Environment, 636, 299-313. https://doi.org/10.1016/j.scitotenv.2018.04.235

Heath, R. L., \& Packer, L. (1968). Photoperoxidation in isolated chloroplasts: I. Kinetics and stoichiometry of fatty acid peroxidation. Archives of Biochemistry and Biophysics, 125(1), 189-198. https://doi.org/10.1016/0003-9861(68)90654-1 
Jiachen, W., Xiangsheng, L., Jun, Y., He, Z., Ying, L., Yubin, F., ... \&Xuewei, H. (2006). Development and prospect of rare earth functional biomaterials for agriculture in China. Journal of Rare Earths, 24(1), 427-431.https://doi.org/https://doi.org/10.1016/S10020721(07)60419-0

Kotelnikova, A., Fastovets, I., Rogova, O., \& Volkov, D. S. (2020). La, Ce and $\mathrm{Nd}$ in the soil-plant system in a vegetation experiment with barley (Hordeumvulgare L.). Ecotoxicology and Environmental Safety, 206, 111193.https://doi.org/10.1016/j.ecoenv.2020.111193

Krzesłowska, M. (2011). The cell wall in plant cell response to trace metals: polysaccharide remodeling and its role in defense strategy. Acta Physiologiae Plantarum, 33(1), 35-51. https://doi.org/10.1007/s11738-010-0581-z

Kucuker, M. A., Wieczorek, N., Kuchta, K., \&Copty, N. K. (2017). Biosorption of neodymium on Chlorella vulgaris in aqueous solution obtained from hard disk drive magnets. PloSOne, 12(4), e0175255.https://doi.org/10.1371/journal.pone.01 75255

Küpper, H., Lombi, E., Zhao, F. J., \& McGrath, S. P. (2000). Cellular compartmentation of cadmium and zinc in relation to other elements in the hyperaccumulator Arabidopsis halleri. Planta, 212(1), 75-84. https://doi.org/10.1007/s004250000366

Lai, Y., Wang, Q., Yang, L., \& Huang, B. (2006). Subcellular distribution of rare earth elements and characterization of their binding species in a newly discovered hyperaccumulatorPronephrium simplex. Talanta, $\quad 70(1), \quad$ 26-31. https://doi.org/10.1016/j.talanta.2005.12.062

Li, L., Zhou, D., Wang, P., \& Peijnenburg, W. J. (2009). Kinetics of cadmium uptake and subcellular partitioning in the earthworm Eiseniafetida exposed to cadmium-contaminated soil. Archives of Environmental Contamination and Toxicology, 57(4), 718-724. https://doi.org/10.1007/s00244-009-9296-9

Liu, C., Hong, F. S., Wu, K., Ma, H. B., Zhang, X. G., Hong, C. J., ... \& Li, Z. R. (2006). Effect of Nd3+ ion on carboxylation activity of ribulose-1, 5-bisphosphate carboxylase/oxygenase of spinach. Biochemical and Biophysical Research Communications, 342(1), 36-43. https://doi.org/10.1016/j.bbrc.2006.01.105

Liu, D., Zheng, S., \& Wang, X. (2016). Lanthanum regulates the reactive oxygen species in the roots of rice seedlings. Scientific Reports, 6(1), 1-7. https://doi.org/10.1038/srep31860

Liu, W. S., van der Ent, A., Erskine, P. D., Morel, J. L., Echevarria, G., Spiers, K. M., ... \& Tang, Y. T. (2020). Spatially resolved localization of lanthanum and cerium in the rare earth element hyperaccumulator fern Dicranopterislinearis from China. Environmental Science \&Technology, 54(4), 2287-2294. https://doi.org/10.1021/acs.est.9b05728
Ma, Y., He, X., Zhang, P., Zhang, Z., Ding, Y., Zhang, J., ... \& Yang, K. (2017). Xylem and phloem based transport of $\mathrm{CeO} 2$ nanoparticles in hydroponic cucumber plants. Environmental Science \&Technology, 51(9), 5215-5221. https://doi.org/10.1021/acs.est.6b05998

Nunes, L. A., Souza, A. S., Carlos, L. D., \& Malta, O. L. (2017). Neodymium doped fluoroindogallate glasses as highly-sensitive luminescent non-contact thermometers. Optical Materials, 63, 42-45. https://doi.org/https://doi.org/10.1016/j.optmat.2016. 08.038

Oyanagui, Y. (1984). Reevaluation of assay methods and establishment of kit for superoxide dismutase activity. Analytical Biochemistry, 142(2), 290-296. https://doi.org/10.1016/0003-2697(84)90467-6

Peng, Q., \& Zhou, Q. (2009). Antioxidant capacity of flavonoid in soybean seedlings under the joint actions of rare earth element La (III) and ultraviolet-B stress. Biological Trace Element Research, 127(1), 69-80. https://doi.org/10.1007/s12011-008-8218-4

Pilon, M., Abdel-Ghany, S. E., Cohu, C. M., Gogolin, K. A., \& Ye, H. (2006). Copper cofactor delivery in plant cells. Current Opinion in Plant Biology, 9(3), 256-263. https://doi.org/10.1016/j.pbi.2006.03.007

Qi, J., Song, C. P., Wang, B., Zhou, J., Kangasjärvi, J., Zhu, J. K., \& Gong, Z. (2018). Reactive oxygen species signaling and stomatal movement in plant responses to drought stress and pathogen attack. Journal of Integrative Plant Biology, 60(9), 805826.https://doi.org/10.1111/jipb.12654

Rauser, W. E. (1999). Structure and function of metal chelators produced by plants. Cell Biochemistry and Biophysics, 31(1), 19-48. https://doi.org/10.1007/bf02738153

Salgado, O. G. G., Teodoro, J. C., Alvarenga, J. P., de Oliveira, C., de Carvalho, T. S., Domiciano, D., ... \&Guilherme, L. R. G. (2020). Cerium alleviates drought-induced stress in Phaseolus vulgaris. Journal of Rare Earths, 38(3), 324-331. https://doi.org/https://doi.org/10.1016/j.jre.2019.07.014

Sun, D., He, N., Chen, Q., \&Duan, S. (2019). Effects of lanthanum on the photosystem II energy fluxes and antioxidant system of Chlorella Vulgaris and PhaeodactylumTricornutum. International Journal of Environmental Research and Public Health, 16(12), 2242. https://doi.org/10.3390/ijerph16122242

Tang, H., Shuai, W., Wang, X., \& Liu, Y. (2017). Extraction of rare earth elements from a contaminated cropland soil using nitric acid, citric acid and EDTA. Environmental Technology, 38(16), 1980-1986. https://doi.org/10.1080/09593330.2016.1244563 
Thomas, P. J., Carpenter, D., Boutin, C., \& Allison, J. E. (2014). Rare earth elements (REEs): effects on germination and growth of selected crop and native plant species. Chemosphere, 96, 5766.https://doi.org/10.1016/j.chemosphere.2013.07.020

Wang, L., Huang, X., \& Zhou, Q. (2009). Protective effect of rare earth against oxidative stress under ultraviolet-B radiation. Biological Trace Element Research, 128(1), 82-93. https://doi.org/10.1007/s12011-008-8250-4

Wang, X., \& Liu, D. (2017). Integration of cerium chemical forms and subcellular distribution to understand cerium tolerance mechanism in the rice seedlings. Environmental Science and Pollution Research, 24(19), 16336-16343.https://doi.org/10.1007/s11356017-9274-0

Wang, Z., Liu, D., Lu, P., \& Wang, C. (2001). Accumulation of rare earth elements in corn after agricultural application. Journal of Environmental Quality, 30(1), 37-45. https://doi.org/10.2134/jeq2001.30137x

Weigel, H. J., \&Jäger, H. J. (1980). Subcellular distribution and chemical form of cadmium in bean plants. Plant Physiology, 65(3), 480-482. https://doi.org/10.1104/pp.65.3.480

Weng, B., Xie, X., Weiss, D. J., Liu, J., Lu, H., \& Yan, C. (2012). Kandeliaobovata (S., L.) Yong tolerance mechanisms to cadmium: subcellular distribution, chemical forms and thiol pools. Marine Pollution Bulletin, 64(11),

2453-2460. https://doi.org/10.1016/j.marpolbul.2012.07.047
Zakotnik, M., Tudor, C. O., Peiró, L. T., Afiuny, P., Skomski, R., \& Hatch, G. P. (2016). Analysis of energy usage in $\mathrm{Nd}-\mathrm{Fe}-\mathrm{B}$ magnet to magnet recycling. Environmental Technology \& Innovation, 5, 117-126. https://doi.org/https://doi.org/10.1016/j.eti.2016.01.002

Zhang, W., Lin, K., Zhou, J., Zhang, W., Liu, L., \& Zhang, Q. (2014). Cadmium accumulation, subcellular distribution and chemical forms in rice seedling in the presence of sulfur. Environmental Toxicology and Pharmacology, 37(1), 348-353. https://doi.org/10.1016/j.etap.2013.12.006

Zhao, C. M., Shi, X., Xie, S. Q., Liu, W. S., He, E. K., Tang, Y. T., \& Qiu, R. L. (2019). Ecological risk assessment of neodymium and yttrium on rare earth element mine sites in Ganzhou, China. Bulletin of Environmental Contamination and Toxicology, 103(4), 565-570. https://doi.org/10.1007/s00128019-02690-2

Zhao, H., \& Yang, Q. (2019). The suitability of rare earth elements for geographical traceability of tea leaves. Journal of the Science of Food and Agriculture, 99(14), 6509-6514. https://doi.org/10.1002/jsfa.9930

Zicari, M. A., d'Aquino, L., Paradiso, A., Mastrolitti, S., \& Tommasi, F. (2018). Effect of cerium on growth and antioxidant metabolism of Lemna minor L. Ecotoxicology and Environmental Safety, 163, 536-543. https://doi.org/10.1016/j.ecoenv.2018.07.113 